\title{
Myth: Intravenous amiodarone is safe in patients with atrial fibrillation and Wolff-Parkinson-White syndrome in the emergency department
}

\author{
Marius A. Tijunelis, MD;* Mel E. Herbert, $\mathrm{MD}^{\dagger}$
}

\begin{abstract}
Wolff-Parkinson-White (WPW) syndrome with atrial fibrillation (AF) is a potentially life-threatening problem requiring rapid conversion to sinus rhythm. The most recent American Heart Association guidelines for the treatment of patients with WPW, published in conjunction with the 2000 Advanced Cardiac Life Support (ACLS) guidelines, suggests that intravenous amiodarone is a firstline therapy for AF-WPW; however the evidence suggests this is a potentially dangerous myth.
\end{abstract}

Key words: amiodarone; cardiac arrest; arrythmia; Wolff-Parkinson-White syndrome; WPW

RÉSUMÉ

Le syndrome de Wolff-Parkinson-White (WPW) avec fibrillation auriculaire est une atteinte mettant en jeu le pronostic vital et qui nécessite une conversion rapide au rythme sinusal. Les lignes directrices de la American Heart Association les plus récentes pour le traitement de patients atteints du syndrome de WPW, publiées conjointement avec les lignes directrices des Soins avancés en réanimation cardiorespiratoire 2000 (RCR), proposent l'amiodarone intraveineuse comme traitement de première intention pour le syndrome de WPW accompagné de fibrillation auriculaire. Cependant, les données suggèrent que cette recommandation est un mythe potentiellement dangereux.

\section{Background}

In 1930, Wolff, Parkinson and White reported 11 cases of young, healthy patients with normal hearts who presented with bundle-branch block, abnormally short P-R intervals, and paroxysms of tachycardia, including supraventricular tachycardia, paroxysmal atrial fibrillation and atrial flutter. ${ }^{1}$ It is now recognized that Wolff-Parkinson-White syndrome (WPW) is a congenital abnormality characterized by the presence of an accessory conduction pathway between the atrium and the common ventricular tissue (Fig. 1).

\section{Diagnosis}

The fundamental physiologic characteristic of WPW is early activation (pre-excitation) of part of the ventricular myocardium by an aberrantly conducted atrial impluse. ${ }^{2}$ Different types of bypass tracts have been identified, with the bundle of Kent (Kent's bundle, or atrioventricular [AV] pathway) being the most common. Bypass tracts can conduct in the antegrade direction, retrograde direction or, sometimes, in both directions, usually causing 1 of 2 tachyarrhythmias: reciprocating tachycardia or atrial fibrillation (AF). The most common of the 2 is a reciprocating

*Assistant Professor of Clinical Emergency Medicine, and †Associate Professor of Clinical Emergency Medicine, KECK USC School of Medicine, Department of Emergency Medicine, LAC+USC Medical Center, Los Angeles County, Los Angeles, Calif.

Received: Sept. 9, 2004; accepted: Nov. 9, 2004

Can J Emerg Med 2005;7(4):262-5 
tachycardia with antegrade conduction through the AV node-His' bundle (band) and retrograde conduction via the accessory pathway. ${ }^{3}$ A less common but more concerning dysrrhythmia is AF (see Fig. 2), which occurs in $10 \%-23 \%$ of patients with $\mathrm{WPW}^{4}$ and places the patient at significantly higher risk of spontaneous ventricular fibrillation. ${ }^{5,6}$ Patients with ECG manifestations of pre-excitation should have a cardiology evaluation because prophylactic accessory-pathway ablation has been shown to reduce the frequency of dysrrhythmic events in patients at high risk. ${ }^{7}$

Patients with WPW often present to the emergency department (ED) in asymptomatic fashion with 3 main ECG criteria: a short $\mathrm{P}-\mathrm{R}$ interval $(<0.12 \mathrm{sec})$, a prolonged $\mathrm{QRS}$ duration $(>0.12 \mathrm{sec})$ and a slurred, delayed upslope in the QRS complex (delta wave). ${ }^{8}$ The prevalence of electrocardiographic pre-excitation is between 1 and 3 per 1000 patients; ${ }^{9}$ however, WPW's intermittent nature makes it difficult to estimate the true prevalence.

\section{The recommendations}

The most recent American Heart Association (AHA) guidelines for the treatment of patients with WPW, published in conjunction with the 2000 Advanced Cardiac Life Support (ACLS) guidelines, ${ }^{10}$ suggest that stable patients with AF-WPW should be converted using direct-current cardioversion or one of the following antiarrhythmics (Class IIb recommendation): $:^{10}$ amiodarone, procainamide, propafenone, flecainide or sotalol.

Amiodarone is a Class III antiarrhythmic agent, Vaughan Williams classification. ${ }^{11}$ Its major therapeutic effect is to

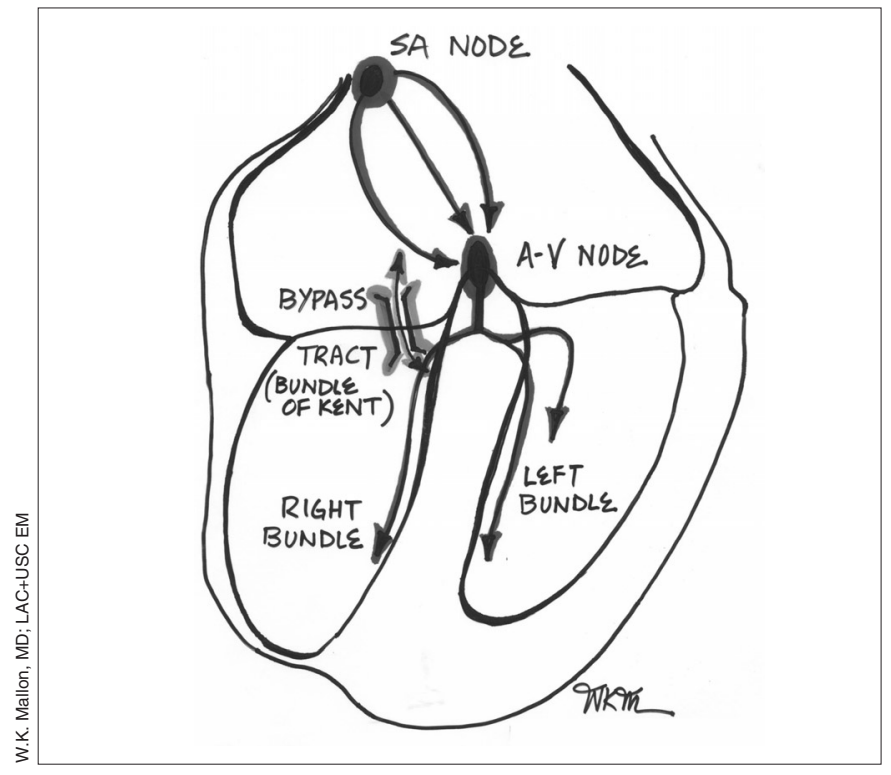

Fig. 1. Wolff-Parkinson-White syndrome prolong the action potential duration and refractoriness of all cardiac fibres. It is proposed that single intravenous amiodarone dose results in depression of $\mathrm{A}-\mathrm{V}$ node conduction with little direct effect on atrial or ventricular properties. ${ }^{12}$

\section{The evidence}

We used the search terms, "Wolff-Parkinson-White," "WPW," "amiodarone," "procainamide," "propafenone," "flecainide," "sotalol" and "ventricular fibrillation" to search the Ovid MEDLINE database for English language randomized trials, case series and case reports published between 1969 and 2003. Studies of oral amiodarone were excluded because of evidence indicating that intravenous and oral amiodarone have different electrophysiologic effects. ${ }^{13}$ Our search revealed no controlled studies in which amiodarone was given to patients with AF-WPW. Conversely, we identified 10 cases in which patients with AF-WPW suffered pro-arrhythmic events after receiving antiarrhythmics (Table 1). ${ }^{14-19}$ Seven of these described ventricular tachyarrhythmias after administration of amiodarone intravenously (IV).

The first documented case of ventricular tachyarrhythmias associated with IV amiodarone administration in AF-WPW was in a 69-year-old man with a history of inferior myocardial infarction and WPW (type A) who presented to the ED with clinical and radiological evidence of left ventricular failure and various irregular narrow- and broad-complex tachycardias with rates of between 130 and 170 beats/min. IV amiodarone $(1200 \mathrm{mg}$ ) was administered over 24 hours. Several hours into the drug infusion period, virtually continuous broad-complex QRS AF ensued and the ventricular rate increased to 230 beats $/ \mathrm{min}$. The patient stayed in hospital for 3 weeks but was ultimately discharged home. ${ }^{15}$

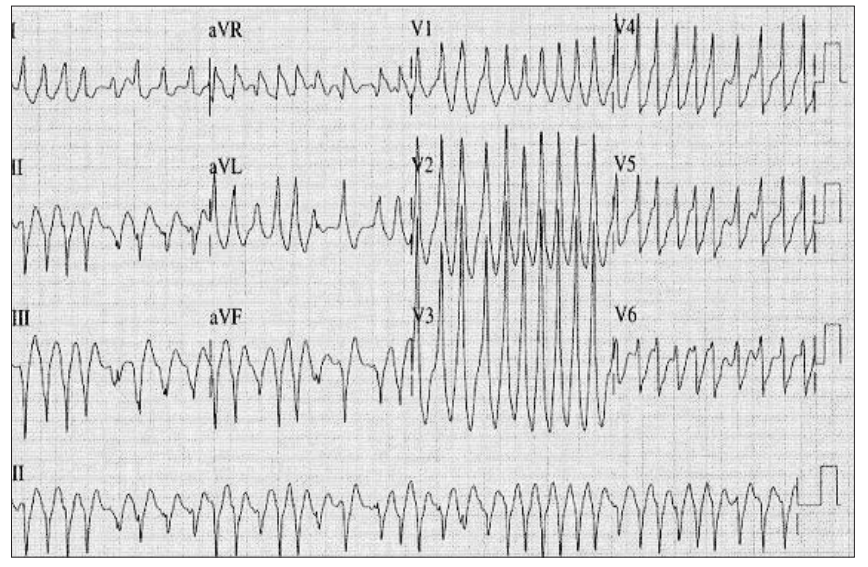

Fig. 2. Atrial fibrillation in a patient with Wolff-ParkinsonWhite syndrome 
Schutzeberger and colleagues published a report of a 60year-old woman with WPW who presented to the ED with spontaneous $\mathrm{AF}$ and a ventricular rate of 140 beats/min, predominantly wide QRS complexes. Intravenous amiodarone $(5 \mathrm{mg} / \mathrm{kg})$ was administered over a 10-minute period. Within 10 minutes of drug administration the ventricular rate increased to 210 beats/min and systolic blood pressure fell to $80 \mathrm{~mm} \mathrm{Hg}$. After 10 minutes, the rate slowed and sinus rhythm was restored. ${ }^{16}$

In 1993 Pastor and colleagues published an abstract ${ }^{18}$ titled "Ventricular fibrillation during treatment of atrial fibrillation with intravenous amiodarone in patients with the WPW syndrome." In this series, 24 of 56 patients had paroxysmal AF and 6 of the 24 (25\%) had cardiac arrest secondary to ventricular fibrillation during a paroxysm of AF. Four of the 6 cardiac arrests occurred during an intravenous infusion of amiodarone.

The final documented case involved a 32-year-old man with recurrent palpitations who was admitted to hospital after a syncopal episode. An ECG on admission showed atrial fibrillation with ventricular pre-excitation and a mean ventricular rate of 250 beats/min. IV amiodarone was ad- ministered ( $5 \mathrm{mg} / \mathrm{kg}$ over $20 \mathrm{~min}$ ), and minutes after the amiodarone bolus the patient collapsed with ventricular fibrillation. Prompt DC shock with $200 \mathrm{~J}$ restored sinus rhythm, and subsequent electrophysiologic studies confirmed the diagnosis of ventricular pre-excitation from a left posteroseptal accessory pathway with an anterograde effective refractory period of 200 msec. $^{19}$

\section{Conclusions}

The lack of evidence showing safety and efficacy, and the presence of several case reports and case series suggesting possible harm strongly suggest that amiodarone is not a preferred treatment for AF-WPW, contrary to ACLS guidelines. As the only therapeutic modality lacking proarrhythmic properties, DC cardioversion is likely the fastest and safest option.

Competing interests: None declared.

\section{References}

1. Wolff L, Parkinson J, White PD. Bundle-branch block with short P-R interval in healthy young people prone to paroxysmal tachycardia. Am Heart J 1930;5:685-704.

Table 1. Pro-arrhythmic events after the administration of an antiarrhythmic

\begin{tabular}{|c|c|c|c|c|c|}
\hline Study & $\begin{array}{l}\text { Study } \\
\text { type }\end{array}$ & $\begin{array}{l}\text { Patient age / } \\
\text { gender }\end{array}$ & Presenting rhythm & Antiarrhythmic, dose & Outcome \\
\hline $\begin{array}{l}\text { Sellers et al, }{ }^{14} \\
(1977)\end{array}$ & EP & Unknown & Induced AF & $\begin{array}{l}\text { Procainamide, } \\
10-12 \mathrm{mg} / \mathrm{kg}, 50 \mathrm{mg} \mathrm{q} 2 \mathrm{~min}\end{array}$ & $\begin{array}{l}\text { Aflutter } 2: 1 \rightarrow \\
\text { Unknown }\end{array}$ \\
\hline $\begin{array}{l}\text { Sellers et al, } \\
\text { (1977) }\end{array}$ & EP & Unknown & Induced AF & $\begin{array}{l}\text { Procainamide, } \\
10-12 \mathrm{mg} / \mathrm{kg}, 50 \mathrm{mg} \mathrm{q} 2 \mathrm{~min}\end{array}$ & $\begin{array}{l}\text { Aflutter } 1: 1 \rightarrow \\
\text { Unknown }\end{array}$ \\
\hline $\begin{array}{l}\text { Sheinman et al, }{ }^{15} \\
\text { (1982) }\end{array}$ & $\mathrm{CR}$ & $69 / M$ & $\begin{array}{l}\text { h/o MI, narrow/broad } \\
\text { complex tach } 130-170 \\
\text { beats/min }\end{array}$ & $\begin{array}{l}\text { Amiodarone, } \\
1200 \mathrm{mg} / 24 \mathrm{~h}\end{array}$ & $\begin{array}{l}230 \text { beats } / \mathrm{min} \rightarrow \\
\text { disopyramide } \\
150 \mathrm{mg} / 2 \mathrm{~min} \rightarrow \mathrm{AF}\end{array}$ \\
\hline $\begin{array}{l}\text { Schutzenberger } \\
\text { et al, }{ }^{16} \\
(1987)\end{array}$ & $\mathrm{CR}$ & $60 / M$ & $\begin{array}{l}\text { Vent rate of } 140 \\
\text { beats/min \& wide QRS } \\
\text { complexes }\end{array}$ & $\begin{array}{l}\text { Amiodarone, } \\
50 \mathrm{mg} / \mathrm{kg} / 10 \mathrm{~min}\end{array}$ & $\begin{array}{l}210 \text { beats } / \mathrm{min} \& \mathrm{SBP} \\
\rightarrow \text { to } 80 \mathrm{~mm} \mathrm{Hg} \rightarrow \\
10 \text { min later NSR }\end{array}$ \\
\hline $\begin{array}{l}\text { Sulke et al, } \\
(1990)\end{array}$ & EP & $40 / F$ & Induced AF & $\begin{array}{l}\text { Propafenone, } \\
35 \mathrm{mg} / 3 \mathrm{~min}\end{array}$ & $\begin{array}{l}\text { Affluter } 1: 1, \text { BP } 90 / 40 \\
\rightarrow \text { NSR spontaneously } \\
\text { at } 13 \text { min }\end{array}$ \\
\hline $\begin{array}{l}\text { Pastor et al, } \\
\text { (1993) }\end{array}$ & EP & $39 / M$ & $\mathrm{AF} \times 4 \mathrm{~h}$ & $\begin{array}{l}\text { Amiodarone, } \\
400 \mathrm{mg} / 5 \mathrm{~min}\end{array}$ & $\begin{array}{l}\text { VF } \rightarrow \\
\text { Unknown }\end{array}$ \\
\hline $\begin{array}{l}\text { Pastor et al, } \\
\text { (1993) }\end{array}$ & EP & $38 / M$ & $\mathrm{AF} \times 6 \mathrm{~h}$ & $\begin{array}{l}\text { Amiodarone, } \\
300 \mathrm{mg} / 10 \mathrm{~min}\end{array}$ & $\begin{array}{l}\mathrm{VF} \rightarrow \\
\text { Unknown }\end{array}$ \\
\hline $\begin{array}{l}\text { Pastor et al, } \\
\text { (1993) }\end{array}$ & EP & $44 / F$ & $\mathrm{AF} \times 6.5 \mathrm{~h}$ & $\begin{array}{l}\text { Amiodarone, } \\
300 \mathrm{mg} / 30 \mathrm{~min}\end{array}$ & $\begin{array}{l}\text { VF } \rightarrow \\
\text { Unknown }\end{array}$ \\
\hline $\begin{array}{l}\text { Pastor et al, } \\
\text { (1993) }\end{array}$ & EP & $18 / \mathrm{M}$ & $A F \times 10 h$ & $\begin{array}{l}\text { Amiodarone, } \\
300 \mathrm{mg} / 5 \mathrm{~min}\end{array}$ & $\begin{array}{l}\text { VF } \rightarrow \\
\text { Unknown }\end{array}$ \\
\hline $\begin{array}{l}\text { Boriani et al, } \\
\text { (1996) }\end{array}$ & EP & $32 / \mathrm{M}$ & $\mathrm{AF}$ at 250 beats $/ \mathrm{min}$ & $\begin{array}{l}\text { Amiodarone, } \\
5 \mathrm{mg} / \mathrm{kg} / 20 \mathrm{~min}\end{array}$ & $\begin{array}{l}\mathrm{VF} \rightarrow \\
200 \mathrm{~J} \rightarrow \mathrm{NSR}\end{array}$ \\
\hline
\end{tabular}

$\mathrm{EP}=$ electrophysiology; $\mathrm{CR}=$ case report; $\mathrm{AF}=$ atrial fibrillation; Aflutter = atrial flutter; $\mathrm{h} / \mathrm{o} \mathrm{MI}=$ history of myocardial infarction; tach = tachycardia; vent rate = ventilation rate; $\mathrm{SBP}=$ systolic blood pressure; $\mathrm{NSR}=$ normal sinus rhythm; $\mathrm{BP}=$ blood pressure 
2. Gaita F, Giustetto C, Riccardi R, Brusca A. Wolff-Parkinson-White syndrome: identification and management. Drugs 1992;43:185-200.

3. Newman BJ, Donoso E, Fridberg CK. Arrhythmias in the Wolff-Parkinson-White syndrome. Prog Cardiovasc Dis 1966; 9:147-65.

4. Campbell RWF, Smith RA, Gallagher JJ, Pritchett ELC, Wallace AG. Atrial fibrillation in the Preexcitation Syndrome. Am J Cardiol 1977;40:514-20.

5. Klein GJ, Bashore TM, Sellers TD, Pritchett EL, Smith WM, Gallagher JJ. Ventricular fibrillation in the Wolff-Parkinson-White Syndrome. N Engl J Med 1979;301:1080-5.

6. Montoya PT, Brugada P, Smeets J, Talajic M, Della Bella P, Lezaun R, et al. Ventricular fibrillation in the Wolff-Parkinson-White syndrome. Eur Heart J 1991;12:144-50.

7. Pappone C, Santinelli V, Manguso F. Augello G, Santinelli O, Vicedomini $G$, et al. A randomized study of prophylactic catheter ablation in asymptomatic patients with the Wolff-Parkinson-White Syndrome. N Engl J Med 2003;349: 803-21.

8. Al-Khatib SM, Pritchett ELC. Clinical features of Wolff-Parkinson-White Syndrome. Am Heart J 1999;138:403-13.

9. Chung KY, Walsh TJ, Massie E. Wolff-Parkinson-White syndrome. Am Heart J 1965;69:116-33.

10. Guidelines 2000 for Cardiopulmonary Resuscitation and Emergency Cardiovascular Care (70-2041). Part 6: advanced cardiovascular life support: section 7: algorithm approach to ACLS emergencies: section 7A: principles and practice of ACLS. The American Heart Association in collaboration with the International Liaison Committee on Resuscitation. Circulation 2000; 102(8 suppl):I136-9.

11. Vaughan Williams EM. A classification of antiarrythmic actions reassessed after a decade of new drugs [review]. J Clin Pharmacol 1984;24(4):129-47.

12. Desai AD, Chun S, Sung RJ. The role of intravenous Amiodarone in the management of cardiac arrhythmias. Ann Intern Med 1997;127:294-303.

13. Wellens HJJ, Brugada P, Abdollah H, Dassen WR. A Comparison of the electrophysiologic effects of intravenous and oral Amiodarone in the same patient. Circulation 1984;69:120-4.

14. Sellers TD Jr, Campbell RW, Bashore TM, Gallagher JJ. Effects of procainamide and quinidine sulfate in the Wolff-Parkinson-White syndrome. Circulation 1977;55(1):15-22.

15. Sheinman BD, Evans T. Acceleration of ventricular rate by amiodarone in atrial fibrillation associated with the Wolff-Parkinson-White syndrome. Br Med J 1982;285:9991000

16. Schutzenberger WS, Leisch F, Gmeiner R. Enhanced accessory pathway conduction following intravenous amiodarone in atrial fibrillation: a case report. Int J Cardiol 1987;16:93-5.

17. Sulke AN, Holt P, Sowton GE. Acceleration of conduction within an accessory pathway with propafenone. Int J Cardiol 1990;28(1):105-7.

18. Pastor A, Almendral JM, Ormaetxe J, Arenal A, Martínez-Alday J, Villacastín J, et al. Ventricular fibrillation during treatment of atrial fibrillation with intravenous amiodarone in patients with the WPW syndrome [abstract]. Eur Heart J 1993;14 (suppl):294.

19. Boriani G, Biffi M, Frabetti L, Azzolini U, Sabbatani P, Bronzetti G, et al. Ventricular fibrillation after intravenous amiodarone in Wolff-Parkinson-White syndrome with atrial fibrillation. Am Heart J 1996;131:1214-6.

Correspondence to: Melherbert@ cbooth.com 